\title{
MEASUREMENT OF NUTRITIONAL INTAKE AMONG SCHOOLCHILDREN: ASPECTS OF METHODOLOGY
}

\author{
SONIA G. TOPP AND JUDITH COOK \\ Department of Clinical Epidemiology and Social Medicine, St. Thomas's Hospital Medical School, \\ London S.E.1 \\ AND \\ A. ELLIOTT \\ County Medical Officer, Kent County Council
}

Dietary surveys can take a number of different forms but may be grouped into two main categories: those in which a dietary history is obtained by recall and those in which a weighed, measured or estimated food record is made at the time of food consumption.

The dietary history survey may be an individually reported record in which details of the food consumed during the previous 24 hours are recalled. An example of this type of survey is that undertaken by Chattaway, Happold, and Happold (1946) who asked subjects to recall all they had eaten during the previous day, then showed them different weighed amounts of the food they had mentioned and asked them to select the amount eaten. Attempts have been made to estimate normal or typical food intake using dietary histories. Zukel et al. (1959) estimated 'usual' dietary intake by collecting histories of a typical day's menu together with a detailed dietary history over a four-week period; Babcock, Church, and Gates (1954) used a 30-minute interview to obtain 'usual' intake, and Burke, Reed, van den Berg, and Stuart (1959) used a comprehensive, crosschecked interview to obtain 'usual' pattern of eating for children. All these methods and modifications of them rely on recall and may therefore be unreliable. In addition, the conversion of reported sizes of portion may be affected by individual variation in those carrying out the conversion (Brewer, 1959). It may, therefore, be more suitable, when diet at the individual level is being investigated in this manner, to use the data to obtain frequencies of intake of different foods rather than to estimate exact quantities.

In dietary surveys in which food intake is measured, weighed or estimated, the record may be of the consumption of a family or of an individual. In the Rowett Research Institute study (1955), the details of family food supply for one week were obtained and the cost and quantities of food calcu- N lated, although the exact quantity of food consumed iv by each individual was not known. In the National Food Survey $(1951,1952)$ which began in 1940 and is repeated every year, a week's record of the quantity and the cost of all foods entering the household is obtained. A method of calculation of individual requirements is then used and a comparison of this with overall household consumption $\vec{\theta}$ is made. Examples of studies using individual $N$ weighed diet records are those undertaken Widdowson (1947), Garry, Passmore, Warnock, ang Durnin (1955), Thomson (1958), Ministry of Healt $\vec{h}$ (1968). In all these, individuals taking part used scales to weigh the food they consumed over a given $\mathbb{D}$ period of time and recorded the amounts in booklets at the time of weighing. One of the drawbacks in this type of study is, however, the need for supervision of recording in order to detect and correct any ambiguities and errors; this tends to limit the number of individuals who may take part in the survey. In addition, bias may be introduced by the ? use of a number of different interviewers. Several studies have been made to assess the extent of observer variation in this type of survey. For $\frac{3}{3}$ example, Church, Clayton, Young, and Foster (1954) showed that interviewers having a similar background and training and working as a team collected com- $\frac{7}{0}$ parable data, and Taylor (1955) found in a similar study that there was no significant difference in data $N$ due to interviewer variation.

The period over which weighed records are N usually carried out is one week, although records of $\sigma$ from one day to several weeks or of intermittently repeated periods have been made. Several studies have attempted to find the optimum length for the of weighed or estimated food record. Young et al. (1952a) followed the course of 18 individuals over four consecutive weekly periods and found that, on $ه$ 
a group basis, variation from week to week did not warrant more than a seven-day record, although on an individual basis more than seven days would be needed.

If records carried out at different times of the year are to be compared, account must be taken of seasonal variation. The National Food Survey (1966) found that in Britain intake of most nutrients was lowest in the spring and greatest in the autumn, the difference being greatest for vitamin C. However, the National Food Survey Committee concluded that these seasonal differences were probably of no nutritional significance with respect to the British Medical Association recommended allowances.

Attempts have been made to compare the reliability of different types of dietary study. van den Berg and Mayer (1954) compared the 24-hour recall record with a comprehensive dietary history. The two methods disagreed widely for basic nutrients, and the authors concluded that the comprehensive dietary history was the better method. Morrison, Russell, and Stevenson (1949) compared a 24-hour recall history with a weighed record for the same 24 hours and found results in which agreement was little better than chance. Huenemann and Turner (1942), in a carefully designed study, compared the detailed dietary history with a repeated 10-14 day weighed record and concluded that no single diet record could be considered typical of a subject's food intake over a period of time, there being marked fluctuations. They concluded that a 'typical' diet for an individual does not exist.

Young, Hagan, Tucker, and Foster (1952b) compared 24-hour recall, dieta.y history, and a seven-day measured dietary record and found that at the individual level the data from the three techniques were not comparable. However, at the group level the seven-day record and the 24-hour recall did give similar results for most nutrients. On balance, therefore, the weighed diet record completed concurrently with food intake appears to be the most suitable study technique for analysis of group differences in a relatively small sample population.

\section{Arms}

The pilot survey was designed as part of a larger study on the nutrition of schoolchildren. Interest in this subject arose in three ways. Firstly, medical officers who undertook school medical examinations in Kent reported that some children showed signs of malnutrition, and it was suggested that a study of the extent of malnutrition in the area should be made. Secondly, a study of data (Topp, Cook, Holland, and Elliott, 1970) from a respiratory survey of schoolchildren in Kent (Holland, Halil, Bennett, and Elliott, 1969) showed that children from smaller families and higher social classes tended to be taller and heavier than children from larger families and lower social classes, and it was felt that an attempt should be made to trace the cause of these differences. Lastly, the Ministry of Health Committee on Medical Aspects of Food Policy was seeking data on the nutrition of schoolchildren as an aid to formulating policy.

The aims of the larger study, of which the pilot study described here forms part, were threefold:

1. to examine the dietary intake of schoolchildren and its relationship to health and socio-economic factors;

2. to investigate the extent and nature of poor nutrition; and

3. to act as a pilot study for a nationwide survey which was being planned by the Ministry of Health (now the Department of Health and Social Security).

The aims of the pilot survey were:

1. to act as an exercise in methodology for the larger study, planned to take place in Kent during 1968 69 , so that any necessary modifications in the design could be made;

2. to test the feasibility of using one week's diet recording in group comparisons;

3. to give information on some factors which might bias the results of this larger survey, i.e., differences between fieldworkers, differences over time, and differences between areas. For example, it was thought that different fieldworkers might influence results, firstly in the way in which they taught the child or mother to carry out the weighing procedure and secondly in their powers of extraction and interpretation of information.

\section{Data Collection}

In spring 1968 a list of children residing and going to school in four areas of Kent was selected from schoolchildren covered in an earlier study of respiratory symptoms (op. cit.). From this the fieldworkers chose 32 fully co-operative children; only fully co-operative children were selected since complete food records were essential to the design of the pilot survey. However, it is impossible to say whether the selection of fully co-operative children only has biased the results of the study. The children were asked to complete a four-week weighed diet record, and their parents answered a comprehensive socio-economic questionnaire which included information on family structure, income, father's occupation, mother's education and working status, child's eating pattern, and heights of father and mother.

A four-week diet record was made using a cumulative method of weighing. All foods eaten and 


\begin{tabular}{|c|c|c|c|c|c|c|}
\hline \multirow{2}{*}{ Time Served } & \multirow{2}{*}{ Description of Food or Drink } & \multicolumn{2}{|c|}{ Weight Served } & \multicolumn{2}{|c|}{ Weight left over } & \multirow{2}{*}{$\begin{array}{c}\text { Please tick items } \\
\text { left over }\end{array}$} \\
\hline & & oz & toz & oz & toz & \\
\hline 6.15 p.m. & $\begin{array}{l}\text { Plate } \\
\text { Roast lamb, lean } \\
\text { Mashed potatoes with milk } \\
\text { Boiled carrots } \\
\text { Gravy } \\
\text { Mint sauce ( } 2 \text { teaspoons) }\end{array}$ & $\begin{array}{r}4 \\
6 \\
9 \\
11 \\
12 \\
12\end{array}$ & $\begin{array}{l}2 \\
0 \\
0 \\
2 \\
1 \\
2\end{array}$ & 5 & 1 & $\begin{array}{l}\sqrt{ } \\
\sqrt{ }\end{array}$ \\
\hline 6.30 p.m. & $\begin{array}{l}\text { Plate } \\
\text { Baked jam sponge } \\
\text { Custard }\end{array}$ & $\begin{array}{l}4 \\
6 \\
9\end{array}$ & $\begin{array}{l}2 \\
1 \\
0\end{array}$ & & & \\
\hline
\end{tabular}

FIG. 1. Extract from a food record book.

drunk were weighed on flat-topped spring balances, graduated in ounces and quarter ounces up to $32 \mathrm{oz}$. The scales were easily adjusted to zero and were read to the nearest $1 \mathrm{oz}$. below on the scale. A food record book (Fig. 1) was provided in which were recorded the time and day of food intake, a description of the food, the cumulative weight of food served, and information on leftovers. Dietary data were collected both at home and at school. Arrangements were made at the child's school to weigh and record the school meal, as it was served, using the same procedure as was used at home.

The design of the study was that of a double latin square operating within each of the four areas and involving the study of eight children by four fieldworkers in each area (district nurses, midwives, and health visitors) for four weeks. The fieldworkers were under the close supervision of two dietitians. Each fieldworker made two initial contacts and supervised two different children each week (Fig. 2) so that each child was eventually supervised by four different fieldworkers.

\begin{tabular}{c|c|c|c|c}
\hline Child & Week 1 & Week 2 & Week 3 & Week 4 \\
\cline { 1 - 2 } $\mathbf{1}$ & A & D & B & C \\
$\mathbf{2}$ & B & C & D & A \\
$\mathbf{3}$ & $\mathbf{C}$ & B & A & D \\
4 & A & B & C & D \\
5 & C & D & A & B \\
6 & D & A & B & C \\
7 & D & A & C & B \\
$\mathbf{8}$ & B & C & D & A \\
\hline
\end{tabular}

Fio. 2. 'Double latin square' allocation of fieldworkers: Fieldworkers: A, B, C, D. Each fieldworker visits two different children each week, totalling eight different visits in the four weeks. This design is repeated for each area.

In the first week the fieldworker filled in the socioeconomic questionnaire and supervised the food recording, a new food book being used in each of the three subsequent weeks. The four weeks of recording for any one child were sometimes spread over periods of up to eight weeks to lessen fieldworker load in any week and to fit in with fieldworkers' and children's holidays.
Initially, it was planned to study each child for eight weeks but this was reduced to four weeks to help ensure the full co-operation of each child during the period of recording. This limited the analysis of the effect of time as long-term variations may not have occurred in the four-week period.

\section{Method of ANALYSIS}

A computer programme was written to calculate the weight of each item served to the child from the cumulative weight of food recorded in the food record. When a weight for leftover food was given in the record, the weight of all food left on the plate was proportioned out to the foods marked as left over in the proportion in which they were served The amount was then subtracted from the served weight of each food in order to estimate the amount actually eaten. Food weights were then converted into weights of nutrients and weights per food group, using food codes and conversion values supplied by the Ministry of Health. The weights per food group were dry weights, allowance having been made for the water content of the foods. The food codes included cooked foods and made-up dishes.

The data under consideration were the mean daily intakes over seven days of the total kilocalories (kcal), and of the following seven nutrients or foods: total protein, riboflavine, vitamin $C$, vitamin $D$, added sugar (sugar taken in tea and coffee and on cereals, etc.), total weight of meat (dry weight of meat including meat in made-up dishes and meat as such), and total weight of confectionery (sweets, chocolates, and ice lollies). The dietitians supervising the study recommended these variables as the most suitable indicators of changes in intake or recording over time.

Each variable was analysed using analysis of variance techniques (Scheffé, 1959) to investigate the following: variation between areas, variation over time, area and time interaction, variation between fieldworkers, and variation between children within areas. 
TABLE II

MEAN DAILY INTAKE FOR EACH WEEK OF SURVEY

\begin{tabular}{|c|c|c|c|c|c|}
\hline Nutrient & Week 1 & Week 2 & Week 3 & Week 4 & Weeks 1-4 \\
\hline $\begin{array}{l}\text { Kilocalories } \\
\text { Total protein (g) } \\
\text { Riboflavine (mg) } \\
\text { Vitamin C (mg) } \\
\text { Vitamin D (i.u.) } \\
\text { Sugar (g) } \\
\text { Meat (oz) } \\
\text { Confectionery: (Dry wt. (g)) }\end{array}$ & $\begin{array}{c}2,370 \\
64 \cdot 5 \\
1 \cdot 48 \\
52 \cdot 4 \\
77 \cdot 8 \\
100 \cdot 8 \\
2 \cdot 34 \\
19 \cdot 6\end{array}$ & $\begin{array}{c}2,445 \\
66 \cdot 4 \\
1 \cdot 45 \\
51 \cdot 3 \\
73 \cdot 1 \\
103 \cdot 6 \\
2 \cdot 43 \\
22 \cdot 8\end{array}$ & $\begin{array}{c}2,285 \\
62 \cdot 6 \\
1 \cdot 40 \\
49 \cdot 2 \\
91 \cdot 4 \\
96 \cdot 8 \\
2 \cdot 45 \\
19 \cdot 4\end{array}$ & $\begin{array}{c}2.212 \\
60 \cdot 2 \\
1 \cdot 38 \\
50 \cdot 1 \\
71 \cdot 9 \\
95 \cdot 0 \\
2 \cdot 22 \\
15 \cdot 2\end{array}$ & $\begin{array}{c}2,328 \\
63 \cdot 4 \\
1 \cdot 44 \\
50 \cdot 6 \\
78 \cdot 6 \\
99 \cdot 0 \\
2 \cdot 36 \\
19 \cdot 3\end{array}$ \\
\hline Numbers & 32 & 32 & 32 & 32 & 32 \\
\hline
\end{tabular}

\section{RESULTS}

Neither fieldworker variation nor area difference had significant influence on the reported intake of any of the eight foods and nutrients studied (Table I). The differences between children in each area were

TABLE I

SIGNIFICANCE LEVELS OF RESULTS

\begin{tabular}{|c|c|c|c|c|c|}
\hline Variable & Area & Time & $\begin{array}{c}\text { Area } \times \\
\text { Time } \\
\text { Inter- } \\
\text { action }\end{array}$ & $\begin{array}{c}\text { Field } \\
\text { worker } \\
\text { within } \\
\text { Area }\end{array}$ & $\begin{array}{c}\text { Child } \\
\text { within } \\
\text { Area }\end{array}$ \\
\hline $\begin{array}{l}\text { Kilocalories } \\
\text { Protein } \\
\text { Riboflavine } \\
\text { Vitamin C } \\
\text { Vitamin D } \\
\text { Sugar } \\
\text { Meat } \\
\text { Confectionery }\end{array}$ & $\begin{array}{l}E \\
z \\
z \\
z\end{array}$ & $\begin{array}{l}* \\
= \\
= \\
=\end{array}$ & $\begin{array}{l}= \\
= \\
=\end{array}$ & $\begin{array}{l}z \\
z \\
z\end{array}$ & $\begin{array}{l}* * * \\
* * * \\
* * * \\
* * * \\
* * * \\
* * *\end{array}$ \\
\hline
\end{tabular}

- Not significant.

$* \mathrm{P}<0.05$.

$* * P<0.001$.

highly significant although, as will be shown later, this is partially explained by differences between age and sex groups.

Differences in daily intake over time for the nutrients studied are shown in Table II. Only kilocalorie and protein intakes showed significant differences between weeks. Mean intakes of both nutrients followed the same pattern of higher intake in the second week, relative to the first, and smaller values in the third and fourth weeks. There also appeared to be a general tendency for intake to decrease with time, expecially for riboflavine, vitamin $\mathrm{C}$, and sugar. The higher intake of vitamin
$D$ in week three is entirely due to two children in one area, who had mean daily intakes of 308.9 i.u. and $191 \cdot 8$ i.u. From the data these amounts seemed atypical of the children with respect to their intakes in other weeks, although they were supervised by different fieldworkers. However, both intakes were found to result from the eating of oily fish (kippers and pilchards). This explains the significant area $\times$ time interaction of vitamin D shown in Table I.

All the nutrients and foods studied, except kilocalories and protein, showed a large within-child random variation and between-child random variation. The overall effects of fieldworkers and time were therefore negligible. In general, kilocalorie and protein intakes had a large between-child variation but a smaller within-child variation.

Further analyses were undertaken using analysis of co-variance methods in an attempt to explain difference in intakes of protein and kilocalories over time, and to measure their relative importance (Table III). Fieldworker and area factors were ignored, and the children were regrouped by age and sex. There were eight children in each of the four age/sex groups which consisted of 14-year-old boys, 14-year-old girls, 12-year-old boys and 12-year-old girls. Differences in intake over time within each child were not found to be significant. Taken in conjunction with the previous results, this indicates that although there was a small time effect on intake in each child, this was not likely to bias results. Compared with the effect of time, the between-child variation was very high, being significant at the $1 \%$ level for both protein and calorie intakes.

TABLE III

SIGNIFICANCE LEVELS OF RESULTS

\begin{tabular}{|c|c|c|c|c|c|c|c|}
\hline Variable & Age & Sex & Sex Interaction & $\begin{array}{l}\text { Child within } \\
\text { Age/Sex }\end{array}$ & $\begin{array}{l}\text { Between } \\
\text { Children }\end{array}$ & Time Linear & $\begin{array}{c}\text { Time } \\
\text { Quadratic }\end{array}$ \\
\hline $\begin{array}{l}\text { Kilocalories } \\
\text { Protein }\end{array}$ & - & $* * *$ & $* * *$ & $* * *$ & $* * *$ & 二 & - \\
\hline
\end{tabular}


The between-child variation was broken down into age and sex components, age $\times$ sex interaction, and between-child variation within each age/sex group. The protein and kilocalorie intakes followed the same pattern of highly significant sex, age $\times$ sex, and child within age/sex group differences but no significant differences between ages appeared. This is explained in Table IV where it is shown that boys

TABLE IV

MEAN DAILY INTAKE

\begin{tabular}{l|c|c|c|c|c}
\hline Variable & $\begin{array}{c}\text { 14-year- } \\
\text { old Boys }\end{array}$ & $\begin{array}{c}\text { 12-year- } \\
\text { old Boys }\end{array}$ & $\begin{array}{c}\text { 14-year- } \\
\text { old Girls }\end{array}$ & $\begin{array}{c}\text { 12-year- } \\
\text { old Girls }\end{array}$ & $\begin{array}{c}\text { All } \\
\text { Children }\end{array}$ \\
\hline Numbers & 8 & 8 & 8 & 8 & 32 \\
\hline $\begin{array}{l}\text { Kilocalories } \\
\text { Protein (g) }\end{array}$ & $\begin{array}{c}2,621 \\
71 \cdot 4\end{array}$ & $\begin{array}{c}2,374 \\
65 \cdot 5\end{array}$ & $\begin{array}{c}2,127 \\
56 \cdot 1\end{array}$ & $\begin{array}{c}2,189 \\
60 \cdot 7\end{array}$ & $\begin{array}{c}2,328 \\
63 \cdot 4\end{array}$ \\
\hline
\end{tabular}

had a higher intake than girls in each age group. The younger girls had a higher intake than the older girls whereas the older boys had a higher intake than the younger boys. The variation between each homogeneous group was highly significant, indicating that the variation between children of one age and sex was large, even compared with differences between the sexes.

\section{Discussion}

Although the conclusions which can be drawn from these analyses are limited by the size of the sample and the method of selection of the participants, the negative findings are of interest. Because of the absence of any significant difference between areas it should be possible to group the results of the four areas together in the main survey without making any modifications. A more important finding is the lack of significant differences between fieldworkers within each area, suggesting that fieldworker bias in the diet recording was negligible. This lack of fieldworker bias is felt to be due in part to the close supervision in the field by the two dietitians. The results are in agreement with the work of Taylor (1955).

The general trend in intake over time of the eight nutrients and foods studied was an increase in the second week and a decrease towards the fourth week. This variation could be due to changes in quality of recording or changes in eating habits. Overall sugar and confectionery intakes did not vary much over time, and as these are the items which were most likely to have been forgotten, the quality of recording seems to have been fairly constant. The overall decrease in protein and kilocalorie intakes was more marked, reaching the $5 \%$ significance level. This may indicate that mothers made a special effort in the first survey week to provide what they considered to be an optimum diet but lapsed towards the fourth week. However kilocalorie and protein intakes within individual children remained fairly constant from week to week, compared with the considerable variation in other intakes.

These within-child variations were very small compared with variations between children and they contributed little towards the total variation. In comparisons between groups of children it therefore appears that the use of the one-week diet record as a method of measuring nutrient intake does not introduce a large bias.

Unfortunately, this study does not take into account seasonal variation, a possible source of bias in the larger study when food records were collected throughout the year.

\section{Summary AND CONCluSIONS}

Thirty-two children resident and attending school in four areas o: Kent completed a four-week weighed diet record giving details of all food consumed. Their parents also completed a socioeconomic questionnaire. The aims of the study were as follows:

1. to test the methodology of a proposed nutrition survey involving a larger number of children;

2. to test the feasibility of a one-week weighed die record in group comparisons; and

3. to consider the importance of fieldworker variation, area variation, and differences over time as sources of bias.

The methodology was found to be generally satisfactory. Intakes of kilocalories and protein, important in the evaluation of nutritional status, were found to be fairly constant within each child from week to week. All three potential sources of bias studied were found to have a negligible influence on the recording of dietary intake. Significant age/sex differences were found, but highly significant differences remained between children within each age/sex group.

The use of a one-week weighed diet record in group comparisons was considered justified.

This work was supported in part by a grant from the Department of Health and Social Security. The study has been made possible by the support and help of many people, especially the staffs of the Kent County Council in the health and education services and in particular by the health visitors, district nurses, and midwives who put in a large amount of time on the study. We are indebted to Dr. W. Berry, Mrs. M. Disselduff, and Dr. S. Darke at the Department of Health and Social Security who provided us with very valuable help in planning the study. Our thanks are due to Mr. S. G. Nicholas for the prepara-

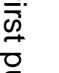


tion of punched cards. We also wish to thank Professor W. W. Holland for advice and the two dietitians, Mrs. A. Melton and Mrs. B. Winstanley, for their enthusiasm and meticulous supervision of the fieldwork.

\section{REFERENCES}

Babcock, M. J., СhurCh, H. N., and Gates, L. O. (1954). Nutritional status of industrial workers. 1. Dietary, blood, and physical findings. Milbank mem. Fd Quart., 32, 323.

BREWER, W. T. (1959). Unpublished data-including 21 one-day records from pilot study conducted by the NC 5 Technical Committee. Compilation of data from pilot study by Harriet Roberts.

Burke, B. S., Reed, R. B., van Den Berg, A. S., and STUART, H. C. (1959). Caloric and protein intakes of children between 1 and 18 years of age. Pediatrics (Supplement), 24, 922.

Chattaway, F. W., Happold, F. C., and Happold, A. M. (1946). Nutrition of schoolchildren in Leeds, winter, 1943, and summer, 1944. Brit. med. J., 1, 429.

Church, H. N., Clayton, M. M., Young, C. M., and Foster, W. D. (1954). Can different interviewers obtain comparable dietary survey data? J. Amer. diet. Ass., 30, 777.

Garry, R. C., Passmore, R., Warnock, G. M., and Durnin, J. V. G. A. (1955). Studies on expenditure of energy and consumption of food by miners and clerks, Fife, Scotland, 1952. Spec. Rep. Ser. med. Res. Coun. (Lond.), No. 289. H.M.S.O., London.

Holland, W. W., Halil, T., Bennett, A. E., and ElliotT, A. (1969). Factors influencing the onset of chronic respiratory disease. Brit. med. J., 2, 205.

HuEnemanN, R. L., and TuRner, D. (1942). Methods of dietary investigation. J. Amer. diet. Ass., 18, 562.

Ministry of Health (1968). A Pilot Survey of the Nutrition of Young Children in 1963. Rep. publ. Hlth med. Subj. No. 118. H.M.S.O., London.

Morrison, S. D., Russell, F. C., and Stevenson, J. (1949). Estimating food intake by questioning and weighing: a one-day survey of eight subjects. Brit. $J$. Nutr., 3, V.

National Food Survey Committef (1951). The Urban Working-Class Household Diet, 1940 to 1949. First Report of the National Food Survey Committee, Ministry of Food. H.M.S.O., London.
(1952). Domestic Food Consumption and Expenditure, 1950. Annual Report of the National Food Survey Committee, Ministry of Food. H.M.S.O., London.

(1966). Domestic Food Consumption and Expenditure: 1964. Annual Report of the National Food Survey Committee, Ministry of Agriculture, Fisheries and Food. H.M.S.O., London.

ROWETT RESEARCH INSTITUTE (1955). Family Diet and Health in Pre-War Britain: A Dietary and Clinical Survey. Carnegie United Kingdom Trust, Dunfermline, Fife, Scotland.

Schefre, H. (1959). The Analysis of Variance. Wiley, New York.

Stuart, H. C., Reed, R. B., Pyle, S. I., Burke, B. S., VAN DEN BERG, A. S., and Valadian, I. (1959). Longitudinal studies of child health and developmentSeries II. Pediatrics, (Supplement), 24, 875.

TAYLOR, H. L. (1955). Report on Survey Procedures. Food Consumption of Rural Families. North Central States 1952. Iowa State College Statistical Lab.

Thomson, A. M. (1958). Diet in pregnancy. Brit. J. Nutr., 12, 446.

Topp, S. G., Cook, J., Holland, W. W., and Elliott, A. (1970). Influence of environmental factors on height and weight of schoolchildren. Brit. J. prev. soc. Med., 24, 154.

VAN Den Berg, A. S., and MAYer, J. (1954). Comparison of one-day food record and research dietary history on a group of obese pregnant women. J. Amer. diet. Ass., $30,1239$.

WidDowson, E. M. (1947). A study of individual children's diets. Spec. Rep. Ser. med. Res. Coun. (Lond.), No. 257. H.M.S.O., London.

Young, C. M., Chalmers, F. W., Church, H. N., Clayton, M. M., Gates, L. O., Hagan, G. C., Steele, B. F., Tucker, R. E., Wertz, A. W., and FosTer, W. D. (1952a). Co-operative nutritional status studies in the Northeast Region. III. Dietary methodology studies. Univ. Mass. agr. Exp. Sta. Bull., No. 469.

-, Hagan, G. C., Tucker, R. E., and Foster, W. D. (1952b). A comparison of dietary study methods. II. Dietary history vs. seven-day record vs. 24-hour recall. J. Amer. diet. Ass., 28, 218.

Zukel, W. J., Lewis, R. H., Enterline, P. E., Painter, R. C., Ralston, L. S., Fawcett, R. M., Meredith, A. P., and Peterson, B. (1959). A short-term community study of the epidemiology of coronary heart disease. A preliminary report on the North Dakota Study. Amer. J. Publ. Hlth, 49, 1630. 